\title{
The Perceived Destination Image of Hangzhou City of China as Received in the Travel Blogs of Western Tourists
}

\author{
Xiao Mali \\ E-mail: xiaomalistudy@hotmail.com \\ BaoYafang \\ E-mail: boyafan@126.com
}

Sun Zhia

School of Tourism and Health,Zhejiang Agriculture\&Forestry

University,,Hangzhou,311300,China

E-mail: curelandscaper@tom.com

\begin{abstract}
This study explored travel blogs as a manifestation of travel experience, along with the destination image of Hangzhou city of China from the perspective of western tourists. Frequency analysis, semantic network analysis as well as content analysis were taken in this study which aims to reveal the perception of western travelers to Hangzhou. The data for this study was from the blogs of western tourists who had been to Hangzhou. Empirical results revealed that the overall perceived destination image of Hangzhou was positive, with particular strengths in tourist attractions and major weaknesses in meals and transportation.
\end{abstract}

Key Words: travel blogs; Hangzhou; destination image; Western tousists.

\section{Introduction}

Destination image which provides an important basis for consumers' purchase destination influences tourist decision making and, consequently, their behavior and destination choices. ${ }^{[1]}$ Destination image formation and psychological characteristics help to shape the image, develop marketing strategy and promote the core competitiveness of a particular destination. ${ }^{[2]}$ In this study, Hangzhou was chosen as the tourist destination for this qualitative blog data collection. In 2011, as the fifth largest inbound tourism city in China, Hangzhou received more than 3 million inbound tourists $-11.1 \%$ increase over the previous year (CNTA, 2012). For selling points of Hangzhou in its outbound tourism market, researchers had reached a consensus - selling points should vary in different markets. Thus, in order to promote the outbound tourism market of Hangzhou in western countries, it is necessary to conduct a study about the destination image of Hangzhou from the perspective of western tourists. Up to now, there are some scholars do have conducted latent researches on the destination image of Hangzhou from 
the aspect of the tourists' perception. However, from the view of travel blogs, few studies have been done. The effects of travel blogs on destination image have been largely overlooked. Blogs present a new and easy means of experience-sharing, where both positive and negative electronic word-of-mouth are exchanged.

This sharing of information has undoubtedly had a direct impact on destination. ${ }^{[3]}$ In this study, frequency analysis, semantic network analysis as well as content analysis are taken which aims to reveal the perception of western travelers to Hangzhou. The data for this study is from the blogs of western tourists who have been to Hangzhou. The purpose of this study was to, from a marketing perspective, assess western tourists' opinions posted on leading Internet travel blogs to better understand the experience being communicated about the strengths and weaknesses of Hangzhou.

\section{Literature review}

\subsection{The perceived destination image and its impact on tourism}

Researchers stated that the perceived destination image plays an important role in consumers' purchase decisions, consequently, their behavior and destination choice ${ }^{[4]}$ Foreign scholars have reaped bumper academic achievement. Gartner put forward eight types of destination image agents, including overt induced I image, overt induced II image, covert induced I image, covert induced II image, autonomous image, unsolicited organic image, solicited organic image and organic image..$^{[5]}$ Echter and Ritchie undertook an empirical analysis, settling the essential elements which engender when the perception striking tourists. ${ }^{[6]}$ Gallarza et al. reviewed the methodologies of empirical studies of destination image. ${ }^{[7]}$

\subsection{Tourist information search behavior and travel blogs}

Tourism is an information-intensive industry and the tourist organization markets their products and builds customer relationships through various channels. Internet has become one of means for tourists to seek travel-related information, which is more effective and flexible compared with the traditional types of media such as advertisements, personal experience, advice from friends and relatives. The development of Internet is inevitable for its extensive source of prepurchase information. It has been found that an increasing number of consumers were relying on online opinions when making decisions ${ }^{[8]}$. which is especially true for tourism products because of their features of exclusivity and untransferability.

In the Internet era, consumers become "the media" themselves. ${ }^{[9]}$ The web provides consumers with various channels, from which they are able to access the others' opinions of tourist destinations. Bloggers judge online blogs to be more trustworthy than other types of media. ${ }^{[10]}$ Travel blogs, as narratives, provide textual artefacts of consumer identity and sensemaking and narrative analysis of these texts offers a commonsense approach to developing a deeper and more meaningful understanding of tourists' experiences and behavior. ${ }^{[11]}$ Recently, researchers suggested that travel blogs provided a new way of understanding consumers' perceptions of a destination, its products, and service. After analyzing travel blogs on Charleston, South Carolina, Pan et al. (2007) identified strengths and weakness of the destination. Choi et al. (2007) compared the image of Macau represented in different online information sources. Similarly, Wenger (2008) analyzed blog entries relating to Austria and found that blog authors are quite different from Austria's market in demographics and touristic characteristics. ${ }^{[12]}$ 


\section{Methodology}

In this study, diverse means were adopted to investigate further relationship between bloggers and the tourist destination as well as grasp insight into the meaning of blogs. The text contained in blog was analyzed by frequency and semantic network analysis, after that, the text of each gathered blog entry was analyzed by content analysis.

\subsection{Data collection}

An essential reason for choosing Google as the search engine is that Google's PageRank algorithm ranks documents based on popularity, which was put forward by Brin and Page in 1998. What's more, Google is generally identified as the most popular and reliable search engine through the world. As a result, two top travel blog sites travelblog.org and travelpod. com were selected in terms of the rank of Google. These sites have a hierarchical directory of blogs (continents, countries, provinces and cities). All travel blogs on China, Hangzhou were downloaded from the two sites. Besides, all travel blogs analyzed in this study were created from December 2005 to April 2012. Totally, 127 blogs were collected up to April 18, 2012. The remaining valid 102 blogs were placed in a master file for qualitative data analysis. Each blog retained its title and identification information.

\subsection{Date analysis}

After detailing the 102 blogs, frequency analysis, semantic network analysis and content analysis were employed in this study. In order to acquire what the greatest concern of western tourists, the frequency analysis was chosen to analyze the full text of 102 blogs. After analyzing, the high- frequency keywords were built into a semantic network. The adjacency of two keywords represents their relative distance of semantic meaning, meanwhile the relative frequencies of words or phrases and the relative distance of them reflect the correlation of their meaning. Content analysis was the third method used in this study. While classifying data, a coding and classification system was adopted to analyze the content efficiently and clearly. As can be seen in Table 1, the categories were labeled meals, hotels, transportation, shopping and attractions. Each category included subcategories. Different evaluation criteria were settled according to different items. The number of the accumulated positives, negatives, neutral comments and the percentage of negatives were the basis of the content analysis.

Table 1 - Category, Subcategory and Evaluation Criteria

\begin{tabular}{|l|c|c|}
\hline \multicolumn{1}{|c|}{ Category } & Subcategory & Evaluation Criteria \\
\hline Meals & $\begin{array}{c}\text { By the type of cuisine } \\
\text { (e.g., Asian, Western) }\end{array}$ & $\begin{array}{c}\text { Price, products, service, } \\
\text { environment, other }\end{array}$ \\
\hline Accommodation & $\begin{array}{r}\text { By the type of accommodation } \\
\text { (e.g., hotels, hostel) }\end{array}$ & $\begin{array}{c}\text { Price, room, service, } \\
\text { environment, other }\end{array}$ \\
\hline Transportation & By the type of transport (e.g., buses, taxies) & $\begin{array}{c}\text { Fare, convenience, environment } \\
\text { and user friendliness, other }\end{array}$ \\
\hline Shopping & By the type of goods (e.g., tea, silk products) & Price, service, other \\
\hline Attractions & By the name of attractions & Positives, negatives \\
\hline
\end{tabular}




\section{Results}

As a manifestation of communicated travel experience, travel blogs express the attitude of visitors towards Hangzhou. The results of frequency, semantic network analysis and content analysis for travel blogs presented the strengths and weaknesses of Hangzhou as a notable tourist destination in detail.

\subsection{Profiles}

The demographic information of bloggers was acquired from the hosting sites where bloggers were permitted to post their personal portraits, disclose their gender and hometown in the traveler profiles. Despite a small minority of bloggers were from Canada, Switzerland, France, Spain and Germany, most of them lived in USA and UK. For those users who disclosed their gender, male users were more than females in this segment, with 30 females (44\%), 38 males (56\%) and 12 blogs owned by couples or families (13\%). For the blog profiles, except for some bloggers posting several pieces for one trip to describe their experience, the most users preferred producing one posting for the description of one trip. The majority of blogs were composed after the trip, and the rest were posted the same day the trip was taken. In the blogs, the number of words ranged from 2 to 3121, and every blogs contained photos.

\subsection{Frequency analysis}

Table 2 revealed the most frequently used keywords or phrases in travel blogs. It demonstrated the priorities travelers focused on, and it expressed many aspects of travel experience in their travel blogs, including meals, accommodation, transportation, shopping and attractions.

Table 2 - Most Frequent Keywords in Blogs for Hangzhou City of China

\begin{tabular}{|c|c|c|c|c|c|}
\hline Keywords & Frequency & Keywords & Frequency & Keywords & Frequency \\
\hline Hangzhou & 307 & boat & 45 & bamboo & 14 \\
\hline West Lake & 136 & silk & 26 & menu & 14 \\
\hline hostel & 97 & Longjing tea fields & 26 & Lingyin temple & 11 \\
\hline bus & 70 & island & 26 & Tea house & 8 \\
\hline bicycle/bike & 67 & history & 24 & Leifeng pagada & 7 \\
\hline taxi/cab & 67 & night market & 19 & willow & 7 \\
\hline hotel & 59 & Buddha & 17 & jasmine & 7 \\
\hline restaurant & 51 & Causeway & 15 & Sony dynasty & 5 \\
\hline museum & 45 & Longjing tea & 14 & & \\
\hline
\end{tabular}

\subsection{Semantic network analysis}

Based on frequency analysis, semantic analysis presented a clear and valuable framework for the construction and analysis of communication content of Hangzhou. In the Figure1, a large frequent occurrence of keywords was illustrated by a larger and darker colored circle and vice versa. As can be seen, Hangzhou is the most dominant cluster with accommodation, transport tools and some other tourist attractions. The second cluster is West Lake as the major tourist attraction of Hangzhou. Three keywords related to Longjing tea field belong to the third cluster. In addition, there is also a small cluster associated with Buddha and Linyin temple. 


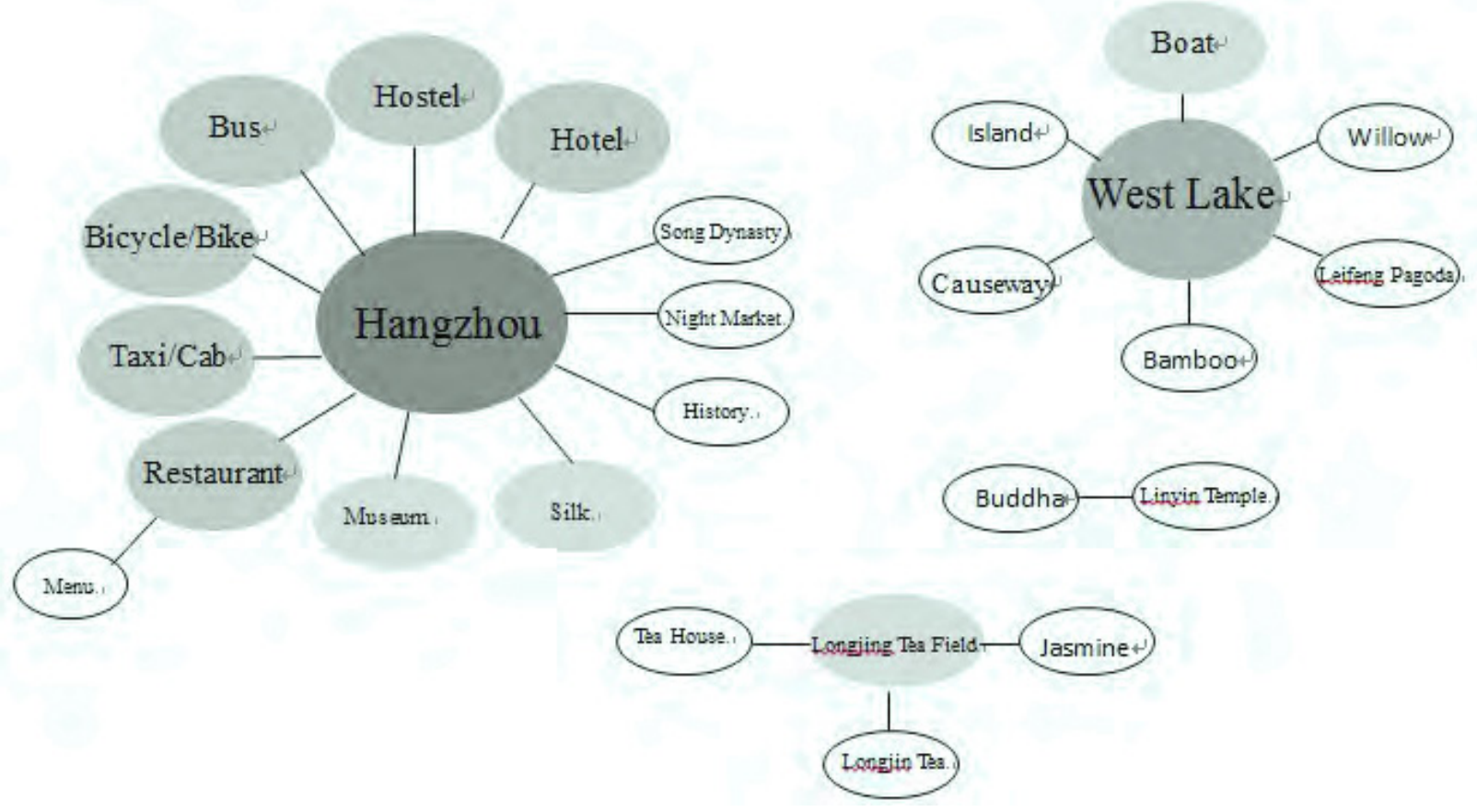

Figure 1 - Semantic Network of Travel Experience to Hangzhou City of China

\subsection{Content analysis}

After the text of each collected blog was analyzed, a coding and classification system was adopted and the texts were categorized by meals, accommodation, transportation, shopping and attractions. Every category included subcategories.

1) Meals

As Table 3 shows, compared with the 51 total sentences of comment, there are only 5 comments for bars and pubs indicating that western tourists attached more attention to Chinese food but less to bars and pubs. Additionally Japanese and Korean food won more praises from bloggers. Specifically, Chinese cuisine was most often commented among bloggers, but its prices generated a relatively large number of negative comments.

Table 3 - Coding Categories and Number of Positive and Negative Comments for Meals

\begin{tabular}{c|c|c|c|c} 
Coding categories & Positives & Negatives & $\begin{array}{c}\text { Total } \\
\text { Sentences }\end{array}$ & $\begin{array}{c}\% \text { of } \\
\text { Negative } \\
\text { Sentence }\end{array}$ \\
\hline Asian food & & & & \\
\hline Chinese food & & & & \\
\hline Price & 1 & 4 & 5 & 80 \\
\hline Products & 27 & 12 & 39 & 31 \\
\hline Environment & 0 & 0 & 0 & 0 \\
\hline Other & 0 & 6 & 6 & 100 \\
\hline Subtotal & 28 & 22 & 50 & 44 \\
\hline & & & & \\
\hline
\end{tabular}




\begin{tabular}{|c|c|c|c|c|}
\hline \multicolumn{5}{|c|}{ Japanese/Korean food } \\
\hline Price & 0 & 0 & 0 & 0 \\
\hline Products & 4 & 0 & 7 & 0 \\
\hline Environment & 0 & 0 & 0 & 0 \\
\hline Other & 4 & 0 & 7 & 0 \\
\hline Subtotal & 8 & 0 & 14 & 0 \\
\hline \multicolumn{5}{|l|}{ Bars and pubs } \\
\hline Price & 0 & 3 & 3 & 100 \\
\hline Products & 1 & 0 & 1 & 0 \\
\hline Environment & 1 & 0 & 1 & 0 \\
\hline Other & 0 & 0 & 0 & 0 \\
\hline Subtotal & 2 & 3 & 5 & 80 \\
\hline \multicolumn{5}{|l|}{ Western food } \\
\hline Price & 0 & 0 & 0 & 0 \\
\hline Products & 2 & 0 & 2 & 0 \\
\hline Environment & 1 & 1 & 2 & 50 \\
\hline Other & 0 & 1 & 1 & 100 \\
\hline Subtotal & 3 & 2 & 5 & 40 \\
\hline Total & 42 & 28 & 70 & 40 \\
\hline
\end{tabular}

\section{2) Accommodation}

Both bloggers who chose hostels and these who preferred hotels poured less attention to price and room. The detailed results are listed in Table4. Regarding hostels, bloggers were discontent with the service and hotels received the most negative comments on environment.

Table 4 - Coding Categories and Number of Positive and Negative Comments For Accommodation

\begin{tabular}{c|c|c|c|c} 
Coding categories & Positives & Negatives & $\begin{array}{c}\text { Total } \\
\text { Sentences }\end{array}$ & $\begin{array}{c}\% \text { of } \\
\text { Negative } \\
\text { Sentence }\end{array}$ \\
\hline Hotel & & & & \\
\hline Price & 0 & 0 & 0 & 0 \\
\hline Room & 0 & 0 & 0 & 0 \\
\hline Environment & 1 & 1 & 2 & 50 \\
\hline Service & 2 & 1 & 3 & 33 \\
\hline Other & 2 & 0 & 2 & 0 \\
\hline Subtotal & 5 & 2 & 7 & 29 \\
\hline & & & & \\
\hline
\end{tabular}




\begin{tabular}{c|c|c|c|c}
\hline Hostel & & & & \\
\hline Price & 1 & 0 & 1 & 0 \\
\hline Room & 1 & 0 & 1 & 0 \\
\hline Environment & 3 & 1 & 4 & 25 \\
\hline Service & 0 & 4 & 4 & 100 \\
\hline Other & 1 & 2 & 3 & 67 \\
\hline Subtotal & 6 & 7 & 13 & 54 \\
\hline Total & 11 & 9 & 20 & 45
\end{tabular}

\section{3) Transportation}

As Table 5 shows, among 26 comments on transportation, $65 \%$ comments were negative. All comments on buses and taxis were negative. In contrast, bicycles and boats received a relatively high proportion of positive comments.

Table 5 - Coding Categories and Number of Positive and Negative Comments for Transportation

\begin{tabular}{|c|c|c|c|c|}
\hline Coding categories & Positives & Negatives & $\begin{array}{c}\text { Total } \\
\text { Sentences }\end{array}$ & $\begin{array}{c}\% \text { of } \\
\text { Negative } \\
\text { Sentence }\end{array}$ \\
\hline \multicolumn{5}{|l|}{ Buses } \\
\hline Convenience & 0 & 1 & 1 & 100 \\
\hline Fares & 0 & 0 & 0 & 0 \\
\hline $\begin{array}{l}\text { Environment } \\
\text { and user } \\
\text { friendliness }\end{array}$ & 0 & 1 & 1 & 100 \\
\hline Other & 0 & 1 & 1 & 100 \\
\hline Subtotal & 0 & 3 & 3 & 100 \\
\hline \multicolumn{5}{|l|}{ Taxis/Cabs } \\
\hline Convenience & 0 & 1 & 1 & 100 \\
\hline Fares & 0 & 0 & 0 & 0 \\
\hline $\begin{array}{l}\text { Environment } \\
\text { and user } \\
\text { friendliness }\end{array}$ & 0 & 1 & 1 & 100 \\
\hline Other & 0 & 4 & 4 & 100 \\
\hline Subtotal & 0 & 6 & 6 & 100 \\
\hline \multicolumn{5}{|l|}{ Bicycles/Bikes } \\
\hline Convenience & 1 & 0 & 1 & 0 \\
\hline Fares & 3 & 0 & 3 & 0 \\
\hline
\end{tabular}




\begin{tabular}{|c|c|c|c|c|}
\hline $\begin{array}{l}\text { Environment } \\
\text { and user } \\
\text { friendliness }\end{array}$ & 1 & 0 & 1 & 0 \\
\hline Other & 0 & 4 & 4 & 100 \\
\hline Subtotal & 5 & 4 & 9 & 44 \\
\hline \multicolumn{5}{|l|}{ Boats } \\
\hline Convenience & 0 & 0 & 0 & 0 \\
\hline Fares & 0 & 1 & 1 & 100 \\
\hline $\begin{array}{l}\text { Environment } \\
\text { and user } \\
\text { friendliness }\end{array}$ & 1 & 0 & 1 & 0 \\
\hline Other & 0 & 0 & 0 & 0 \\
\hline Subtotal & 1 & 1 & 2 & 50 \\
\hline \multicolumn{5}{|l|}{ Trains } \\
\hline Convenience & 1 & 0 & 1 & 0 \\
\hline Fares & 1 & 0 & 1 & 0 \\
\hline $\begin{array}{l}\text { Environment } \\
\text { and user } \\
\text { friendliness }\end{array}$ & 1 & 0 & 1 & 0 \\
\hline Other & 0 & 3 & 3 & 100 \\
\hline Subtotal & 3 & 3 & 6 & 50 \\
\hline Total & 9 & 17 & 26 & 65 \\
\hline
\end{tabular}

\section{4) Shopping}

As shown in Table 6, shopping in Hangzhou received a total of 27 comments, one-third of which were negative. The categories that had the highest percentage of positive comments were tea and silk products, especially for silk products, all comments of which were positive. However the range of clothing and accessories, appliances and digital products fall shorts of expectation.

Table 6 - Coding Categories and Number of Positive and Negative Comments for Shopping

\begin{tabular}{c|c|c|c|c} 
Coding categories & Positives & Negatives & $\begin{array}{c}\text { Total } \\
\text { Sentences }\end{array}$ & $\begin{array}{c}\% \text { of } \\
\text { Negative } \\
\text { Sentence }\end{array}$ \\
\hline Tea & 1 & 0 & 0 & 0 \\
\hline Price & 4 & 0 & 4 & 0 \\
\hline Products & 3 & 1 & 4 & 25 \\
\hline Other & 8 & 1 & 9 & 11 \\
\hline Subtotal & &
\end{tabular}




\begin{tabular}{|c|c|c|c|c|}
\hline \multicolumn{5}{|l|}{$\begin{array}{c}\text { Silk } \\
\text { products }\end{array}$} \\
\hline Price & 0 & 0 & 0 & 0 \\
\hline Products & 1 & 0 & 1 & 0 \\
\hline Other & 1 & 0 & 1 & 0 \\
\hline Subtotal & 2 & 0 & 2 & 0 \\
\hline \multicolumn{5}{|c|}{$\begin{array}{c}\text { Clothing and } \\
\text { acessories }\end{array}$} \\
\hline Price & 0 & 3 & 3 & 100 \\
\hline Products & 0 & 0 & 0 & 0 \\
\hline Other & 1 & 0 & 1 & 0 \\
\hline Subtotal & 1 & 3 & 4 & 75 \\
\hline \multicolumn{5}{|l|}{ Jewelry } \\
\hline Price & 1 & 0 & 1 & 0 \\
\hline Products & 0 & 0 & 0 & 0 \\
\hline Other & 0 & 0 & 0 & 0 \\
\hline Subtotal & 1 & 0 & 1 & 0 \\
\hline \multicolumn{5}{|l|}{ Groceries } \\
\hline Price & 1 & 0 & 1 & 0 \\
\hline Products & 0 & 1 & 1 & 100 \\
\hline Other & 4 & 1 & 5 & 25 \\
\hline Subtotal & 5 & 2 & 7 & 29 \\
\hline \multicolumn{5}{|c|}{$\begin{array}{l}\text { Appliances and } \\
\text { digital products }\end{array}$} \\
\hline Groceries & 0 & 3 & 3 & 100 \\
\hline Price & 0 & 0 & 0 & 0 \\
\hline Products & 1 & 0 & 1 & 100 \\
\hline Other & 1 & 3 & 4 & 75 \\
\hline Subtotal & 18 & 9 & 27 & 33 \\
\hline
\end{tabular}

\section{5) Attractions}

The results revealed the diversity of travel experience in Hangzhou. As shown in Table7, attractions in Hangzhou received a total of 146 comments, only $6 \%$ of which were negative. Compared with other 4 categories, attractions received the highest percentage of positive comments. 
Table 7 - Coding Categories and Number of Positive and Negative Comments for Shopping

\begin{tabular}{|c|c|c|c|c|}
\hline Coding categories & Positives & Negatives & $\begin{array}{c}\text { Total } \\
\text { Sentences }\end{array}$ & $\begin{array}{c}\% \text { of } \\
\text { Negative } \\
\text { Sentence }\end{array}$ \\
\hline West Lake & 37 & 2 & 39 & 5 \\
\hline Leifeng Pagada & 5 & 0 & 5 & 0 \\
\hline Botanical Gardens & 1 & 0 & 1 & 0 \\
\hline Yue-Wang Temple & 1 & 0 & 1 & 0 \\
\hline $\begin{array}{c}\text { Dreaming of the Tiger } \\
\text { Spring }\end{array}$ & 2 & 0 & 2 & 0 \\
\hline YunQi bamboo path & 3 & 0 & 3 & 0 \\
\hline Linyin Temple & 5 & 0 & 5 & 0 \\
\hline Klippe & 1 & 2 & 3 & 27 \\
\hline Longjing Tea Fields & 14 & 1 & 15 & 7 \\
\hline Wushan Square & 1 & 0 & 1 & 0 \\
\hline Museum & 57 & 2 & 59 & 3 \\
\hline Song Dynasty & 5 & 0 & 5 & 0 \\
\hline $\begin{array}{l}\text { Wushan Birds and } \\
\text { Flower Market }\end{array}$ & 1 & 0 & 3 & 67 \\
\hline Hideout of Linbiao & 1 & 0 & 1 & 0 \\
\hline Chongyi Church & 3 & 0 & 3 & 0 \\
\hline Overall Impression & 28 & 5 & 33 & 15 \\
\hline Total & 165 & 14 & 179 & 78 \\
\hline
\end{tabular}

\subsection{Strengths and Weaknesses as Reflected from Travel Blogs on China, Hangzhou}

A total of 341comments were extracted from 102 western travels' blogs, with 253 positive and 88 negative comments. Strengths and weakness identified in the coding process, as shown in the Figure2. Three out of four comments were positive (74.2\%), that is to say, most travellers expressed their favor to Hangzhou. Looking at the major categories, the results showed that attractions were the major strengths of Hangzhou while most complaints came from meals and transportation. 


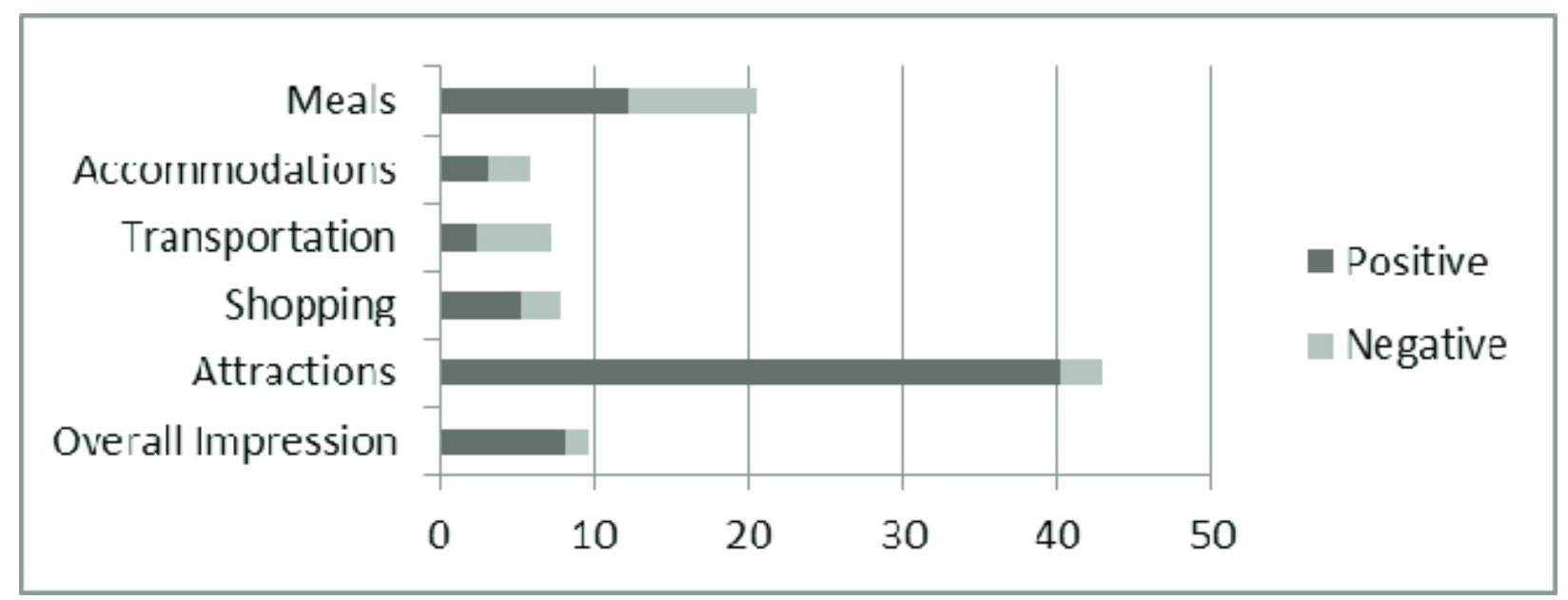

Figure 2 - Percent of Positive and Negative Sentences in Travel Blogs on Hangzhou

\section{Conclusions}

This study analyzed the destination image of Hangzhou as revealed in the travel blogs of western tourists. Analysis of blogs on travels in Hangzhou revealed strengths and weaknesses of this city. The results revealed that the major strengths of the destination of Hangzhou lie in its attractions. Besides the West Lake which is the most charming attraction, the temples and museums also received a wide range of praise. The major weaknesses of Hangzhou were meals and transportation. There were unfavorable perceptions about the price of food and beverage and service of restaurants, which ask local restaurants to control the price as well as improve the service. As for the transportation, bloggers' complaints were mainly about traffic congestion which caused by the growing number of vehicles and the traffic violations of drivers, passengers as well as pedestrian. Additionally, foreigners also confused about the language barrier which was a big factor affecting their trips. Thus, to solve the traffic problems, Hangzhou government should intensify the publicity and education to improve the levels of citizen qualities. Furthermore, in order to improve the service on accommodation, hotels and hostels need to recruit good workers as well as organize staff training. Lastly, marketers have to orient Hangzhou tourism to the needs of public, highlight the strengths of Hangzhou as a tourist attraction and send the correct message conceptually to western travelers.

It is important to note several limitations of the study. First, the findings were not generalizable over foreign visitors to Hangzhou. The sample was not stratified based on demographic variables such as nationality, age and gender. Second, only manifest content was analyzed in this study. In the course of this research, myriads of photos were found along with the main text. Hence, future research analyzing the study with visual pictures to obtain a more comprehensive understanding of the image of destination would provide more comprehensive implications.

\section{References}

${ }^{[1]}$ K.S. Chon. The role of destination image in tourism: A review and discussion [J]. The Tourist Review,1990,2 :2-9 
${ }^{[2]}$ R.C. Mill, and A.M. Morrison. The tourism system: An introductory text [M]. Englewood Cliffs, NJ: Prentice-Hall,1992

${ }^{[3]}$ R Law, and Shannon Cheung, The Perceived Destination Image of Hong Kong as Revealed in the Travel Blogs of Mainland Chinese Tourists [J]. International Journal of Hospitality \& Tourism Administration,2010,11(4):303-327

${ }^{[4]}$ K.S. Chon, The role of destination image in tourism: A review and discussion [J]. The Tourist Review,1990,2:2-9

${ }^{[5]}$ W.C. Gartner, Image formation process[J]. Journal of Travel \& Tourism Marketing, $1993,2(2 / 3)$ : 191-215

[6] C.M.Echtner, and J.R. Ritchie, The measurement of destination image: An empirical assessment[J]. Journal of Travel Research, 1993,31(4): 3-13

${ }^{[7]}$ M.G. Gallarza, I.G. Saura, and H.C..Garcia, Destination image: Towards aconceptual framework[J]. Annals of Tourism Research, 2002,29(1): 56-78

${ }^{[8]}$ L.Guernsey, Suddenly, everybody's an expert on everything[M]. New York Times. 2000

${ }^{[9]} \mathrm{G}$. Thevenot, Blogging as a social media[J]. Tourismand Hospitality Research,2007,7:287-289

${ }^{[10]}$ T.J. Johnson, and B.K. Kaye, Wag the blog: Howreliance on traditional media and the Internet influence credibility perceptions of weblogs among blog users [J].Journalism and Mass Communication Quarterly, 2004,81:622-642

${ }^{[11]} \mathrm{S}$. McCabe, and C. Foster, The role and function of narrative in tourist interaction [J].Journal of Tourism and Cultural Change, 2006,4(3):194-215

${ }^{[12]} \mathrm{Xu} \mathrm{Li}$, and Youcheng Wang, China in eyes of Western Travelers as Repesented in Travel Blogs. Journal of Travel \& Tourism Marketing,2011, 28(7): 689-719 